\title{
ІННОВАЦІЙНІ МЕТОДИ ФОРМУВАННЯ ПРОФЕСІЙНОЇ КОМПЕТЕНТНОСТІ МАЙБУТНІХ МЕДИЧНИХ СЕСТЕР
}

\author{
т. Рудницька

\begin{abstract}
Відокремлений підрозділ «Рокитнівський фаховий медичний коледж» комунального закладу вищої освіти «Рівненська медична академія» Рівненської обласної ради»
\end{abstract} \\ У статті наведено результати педагогічного експерименту щодо формування професійної \\ компетентності майбутніх медичних сестер в умовах медичного коледжу з використанням аналізу \\ педагогічних ситуацій, так званого кейс-методу. Проведені дослідження показали рівень і критерії \\ сформованості професійних компетенцій майбутніх медичних сестер та перспективи їх розвитку за \\ допомогою інноваційних технологій і форм роботи.
}

\section{INNOVATIVE METHODS OF FORMATION PROFESSIONAL COMPETENCE OF FUTURE NURSES}

\author{
T. Rudnytska
}

\section{Separate subdivision "Rokytne Professional Medical College" of the communal institution of higher education "Rivne Medical Academy" of Rivne Regional Council}

The article presents the results of a pedagogical experiment on the formation of professional competence of future nurses in a medical college using the analysis of pedagogical situations, the so-called case method. The conducted research showed the level and criteria of formation of professional competencies of future nurses and prospects of their development with the help of innovative technologies and forms of work.

Вступ. В умовах сьогодення необхідно звернути увагу на сестринський персонал, перейти до розуміння необхідності створення нових можливостей і умов для удосконалення медичних сестер у професійному розвитку, підвищення рівня компетентності, бо саме вони надають комплекс профілактичнолікувально-діагностичних послуг, спрямованих на медичні, соціально-психологічні потреби пацієнта та сім'ї, участь в санітарній просвіті населення та промоції здорового способу життя. Підготовка майбутніх конкурентоспроможних медичних сестер повинна бути спрямована на формування у них не тільки основ професіоналізму, а й готовності до участі в зціленні та збереженні здоров'я і забезпеченні активного довголіття пацієнтів. Професіоналізм медичних сестер в епоху технологізації їх повсякденної практичної діяльності набуває нового змісту і перспектив, одночасно залишаючись важливим моральним фактором професійного співробітництва з лікарем і взаєморозуміння з колегами та пацієнтами [1].
Основна частина. Педагогічний експеримент із формування професійної компетентності майбутніх медсестер проведено на базі Рокитнівського фахового медичного коледжу комунального закладу вищої освіти «Рівненська медична академія». У ході експерименту виділено дві групи: експериментальна і контрольна. У кожну входило по 25 студентів I курсу зі спеціальності 223 «Медсестринство», галузі знань 22 «Охорона здоров'я». Опановуючи навчальну дисципліну «Основи медсестринства», контрольна група навчалася за традиційною програмою, експериментальна група - з використанням праксеологічного підходу, а також інноваційних технологій і форм роботи.

На основі праксеологічного підходу відбувається безпосередня орієнтація освітнього процесу в медичних навчальних закладах на практичну спрямованість, яка передбачає використання практико зорієнтованих завдань у контексті майбутньої професійної діяльності студентів. 
Проаналізовано педагогічні ситуації, так званий кейс-метод: під кейсом розуміється розбір ситуації або конкретного випадку, при якому студенти і викладач беруть участь в безпосередньому обговоренні конкретної ситуації. У навчальному процесі використаний метод ситуаційного аналізу, який відображає реальні життєві ситуації та формує конкретні практичні вміння і навички. Навчальне призначення такого кейса зводиться до закріплення знань, умінь і навичок. Завдання кейс-методу полягає в тому, щоб студент не спрощував ситуацію, а намагався їі пояснити, щоб він умів виокремлювати головне та приймати рішення з урахуванням можливих наслідків і перешкод. На заняттях найбільші труднощі у студентів становить планування сестринського догляду. Більшість з них не вміє приймати обґрунтовані рішення щодо тієі чи іншої проблеми. Тому для економії навчального часу їм пропонують написати в щоденниках мету і план щодо виявлення проблеми. Студент проводить уявний експеримент, прогнозує, що потрібно зробити, щоб усунути проблему. Після формування висновків вони обговорюють їх в аудиторії і спільно з викладачем приймають найефективніше рішення.

Завдяки своїй особливості кейс-метод вирішує кілька завдань. По-перше, при вирішенні деяких кейсів студенту потрібно користуватися не тільки, знаннями, які він отримав на лекції, а й вивчати і аналізувати різний додатковий матеріал, який може бути додатком до кейса: статистичні дані, коментарі учасників обговорення тощо. По-друге, учасники обговорення потрапляють в творчий процес пізнання, це відбувається завдяки вільному висловлюванню ідей і пошуку рішень. По-третє, обговорення може відбуватися в групі, завдяки цьому студенти вчаться працювати командою, що приводить до збільшення одержуваного результату. Застосовуючи кейс-метод, можна використовувати всі види оцінок: поточну, проміжну і підсумкову. Поточна оцінка допомагає керувати процесом обговорення кейса; проміжна оцінка дозволяє фіксувати просування учня шляхом вирішення кейса; підсумкова - підсумовує успіхи в аналізі кейса і оволодінні дисципліною [2]. Застосування кейс-методів у навчанні сестринської справи дозволяє створити на занятті сприятливе середовище для відпрацювання практичних умінь, необхідних навичок для грамотної роботи з різною інформацією, дозволяє активізувати теоретичні знання і практичний досвід учнів, їх здатність висловлювати власні думки, ідеї, пропозиції, вміння вислухати альтернативну точку зору, і арґументовано висловити свою.

Метод ситуаційно-рольової гри ставить студента в ситуацію, максимально наближену до умов його майбутньої професійної діяльності, та створює ефект реальності [3].

Експериментальне дослідження з вивчення курсу включало:

- виявлення можливості підвищення результативності формування професійних компетенцій у майбутніх медичних сестер;

- визначення особливості формування професійних компетенцій;

- забезпечення теоретичними знаннями і практичними роботами майбутніх медсестер при формуванні у них професійних компетенцій.

Проведені дослідження показали рівень і критерії сформованості професійних компетенцій майбутніх медичних сестер. Рівні професійних компетенцій учасників ми позначили як «низький», «середній», «Високий».

Доведено, що професійні компетенції та особистісні якості учасників експериментальної групи якісно змінилися. Експериментальні роботи, виконані на останньому етапі дослідження, показали, що розроблені педагогічні основи формування професійних компетенцій майбутніх медичних сестер підвищують їх результативність.

Розроблено і теоретично обґрунтовано модель формування професійної компетентності майбутніх медичних сестер у процесі фахової підготовки.

На завершення експерименту було проведено міні-опитування серед учасників експериментальної групи, щоб з'ясувати їх ставлення до змісту і якості прослуханого курсу. Питання анкети:

1. Чи задоволені Ви змістом курсу?

2. Чи позитивно вплинув вивчений курс на Ваше формування як спеціаліста та поповнення багажу знань, умінь і навичок?

3. Чим було цікавим (нецікавим) викладання курсу?

За результатами міні-опитування, задоволені змістом курсу 85 \% опитаних студентів. 70 \% вважають, що, порівняно зі заняттями з інших предметів, використано багато інноваційних технологій, їм було дуже цікаво.

Висновки. Використання кейс-методу протягом навчального циклу сприяло розвитку вміння аналізувати ситуації, оцінювати альтернативи, вибирати 
оптимальний варіант і планувати його здійснення. Розроблені педагогічні основи формування про-

\section{СПИСОК ЛІТЕРАТУРИ}

1. Ладыгина Е. Е. Профессиональное становление сестринского персонала в процессе обучения / Е. Е. Ладыгина, М. Н. Михайловский // Медицинская сестра. 2015. - № 5. - С. 47-48.

2. Закусилова Т. О. Формування фахових умінь та навичок у контексті професійної компетентності май- фесійних компетенцій майбутніх медичних сестер підвищують їх результативність.

бутніх медичних сестер: теоретичний аспект / Т. О. Закусилова // Український психолого-педагогічний науковий збірник. - 2016. - № 8. - С. 32-36.

3. Литвинова А. Е. Формування компетентності медичних сестер / А. Е. Литвинова // Медсестринство. - 2017. № 4. - C. 16-18.

Отримано 31.03.21 